\title{
Humanismo e Fenomenologia: na psicologia, na psicopatologia e na psicoterapia
}

\author{
José Célio Freire ${ }^{1}$ \\ Universidade Federal do Ceará, Fortaleza-CE, Brasil
}

Moreira, V. (2009) Clínica humanista-fenomenológica: Estudos em psicoterapia e psicopatologia crítica. São Paulo: Annablume.

O livro tem o mérito de reunir textos esparsos (publicados entre 2001 e 2008) que, revisados e reformatados, adquirem uma organicidade surpreendente e apontam para uma proposta humanístico-fenomenológica madura, alicerçada na filosofia de Merleau-Ponty e em estudos transculturais. Ao todo são quatorze capítulos que mesclam o enfoque em psicoterapia com a proposta de uma (re)leitura psicopatológica, passando pela elaboração de um modelo de supervisão clínica e um delineamento de investigação fenomenológica mundana. Ensaia, ainda, uma compreensão da depressão que a liga à dimensão da alteridade para depois voltar-se detidamente a esse fenômeno tardo-moderno através de uma pesquisa multicentro - realizada em Fortaleza (Ceará, Brasil), Santiago (Chile) e Boston (EUA).

Já na introdução a autora nos apresenta seus principais acompanhantes durante uma trajetória iniciada nos anos 1980. São eles, Carl Rogers, Merleau-Ponty e Arthur Tatossian. Assim, o Enfoque Centrado na Pessoa, a Fenomenologia Mundana e a Psicopatologia Fenomenológica, conduziram-na a uma perspectiva ao mesmo tempo humanista (embora histórica e crítica) e fenomenológica (mas de uma fenomenologia mundana, existencial e experiencial).

Se tomarmos a obra como um todo perceberemos que o fio condutor é a busca de uma compreensão do homem, e de seu sofrimento, a partir de seu mundo vivido, de sua realidade cultural, pressupondo a mútua constituição homem-mundo. Disso decorre a crítica a toda psicologia que trabalhe com dicotomias do tipo corpo-alma, sujeito-objeto, interior-exterior, indivíduo-sociedade, e para tanto o conceito de carne e a perspectiva dos múltiplos contornos, em Merleau-Ponty, servirão de ancoragem para a compreensão do homem enquanto ser-no-mundo.

O texto em apreço permite seu uso diferenciado em algumas disciplinas da graduação e da pós-graduação em Psicologia, e na formação em Psiquiatria. Transcende a literatura comum na área, que acaba por reprisar insistentemente os

1 Endereço para correspondência:

José Célio Freire. Av. Rui Barbosa, 539. Apto.703. Meireles. CEP: 60.115-220. Fortaleza-CE, Brasil. E-mail: jcfreire@ufc.br conceitos básicos da fenomenologia de um primeiro Husserl sem se achegar da fenomenologia que pode ser percebida em abordagens psicológicas consideradas fenomenológicoexistenciais, pelos seus seguidores, e vitalistas e naturistas, pelos seus críticos.

Sem forçar qualquer aproximação com Heidegger, mas assimilando-o via Merleau-Ponty, insere o leitor em campos tão distintos quanto o da teorização psicológica, o da prática psicoterápica, o da pesquisa acadêmica, o da doença mental, o da crítica da cultura e o da ecologia humana.

De fato, Virginia Moreira fecha um périplo que começou com seu primeiro livro, Más Allá de La Persona: hacia uma psicoterapia fenomenológica mundana (2001) - traduzido para o português como De Carl Rogers a Merleau-Ponty: a pessoa mundana em psicoterapia (2007) - no qual faz uma "desconstrução crítica da prática rogeriana", segundo seu ex-orientador de Doutorado Alfredo Naffah Neto, no prefácio à edição brasileira. Depois veio o segundo - Personalidade, Ideologia e Psicopatologia Crítica (2002), em parceria com Tod Sloan. Ali Virginia Moreira já exercitava sua psicopatologia crítica, a partir de uma preocupação social profunda.

No livro atual, os três primeiros capítulos servem a uma discussão epistemológica da psicologia que se pretende fenomenologia. Tal discussão deve acontecer no âmbito de disciplinas que trabalhem as bases teórico-filosóficas das abordagens ditas fenomenológico-existenciais. O quarto e quinto capítulos discutem a intervenção psicológica e a supervisão em psicoterapia a partir da filosofia merleaupontyana, o que pode auxiliar enormemente a formação de psicólogos nesta linha, tanto nas disciplinas profissionalizantes quanto nos estágios supervisionados. Do sexto ao décimo primeiro capítulos temos uma inserção no terreno da psicopatologia enquanto estudo, experiência de adoecimento e pesquisa. Isso afeta diretamente os estudos psicopatológicos da graduação em Psicologia e linhas de pesquisa na pósgraduação. Já os capítulos 12, 13 e 14 ocupam-se da relação entre cultura/ecologia e psicopatologia, abrindo o leque de convergências para o âmbito da psicologia social.

Insistamos numa questão: os textos sobre perspectivas fenomenológicas da psicologia que nos chegam tratam geralmente ou de elementos extraídos, com ou sem muita 
propriedade, da teorização filosófica, ou de defesas intransigentes de práticas autonomeadas como fenomenológicoexistenciais. Na realidade, pouco se leu dos precursores de uma psicologia, psicopatologia e psicoterapia fenomenológicas (tarefa hercúlea a que se propôs Arthur Tatossian em A Fenomenologia das psicoses, por exemplo). Virginia Moreira, neste livro, permite-nos o trânsito entre a teorização de base e a intervenção psicológica de ponta. É uma ponte pênsil talvez, haja vista a crítica epistemológica que sempre ronda as formulações desse campo. As muitas modalidades do veio fenomenológico nas psicologias só tende a agravar o problema, mas a autora deixa clara a sua opção pela filosofia de Merleau-Ponty.

José Célio Freire é Professor Associado do Departamento de Psicologia da Universidade Federal do Ceará.

Recebido: $17 / 11 / 2008$

$1^{a}$ revisão: $10 / 12 / 2008$

Aceite final: 27/12/2008 